\title{
An empirical investigation of the channels that facilitate a total quality culture
}

\author{
David Gallear and Abby Ghobadian \\ Centre for Interdisciplinary Strategic Management Research \\ Middlesex University Business School
}

The Burroughs, London, NW4 4BT

\begin{abstract}
It is generally agreed that the culture of an organisation is a function of its values, beliefs and behavioural practices and that the influence of culture on an organisation is powerful and pervasive. There is also broad agreement that total quality management (TQM ) is a management paradigm that propagates certain values, behaviour and working methods. Moreover, that the successful introduction and practice of a total quality management approach requires close attention to, and more often than not modification of, organisational culture. Yet, culture is somewhat intangible, and regardless of the precise cultural aspirations, in order to change or maintain the desired culture an organisation needs a set of facilitating channels. These are mechanisms or necessary conditions that influence, mould and help sustain a desirable cultural orientation. This paper examines the channels that facilitate the development of a total quality culture based on the findings of an investigation of an international sample of organisations widely regarded as leading exponents of TQM.
\end{abstract}

Keywords: Total quality management, culture, empirical investigation, facilitators 


\section{Introduction}

Many scholars consider culture as a key factor underpinning organisational success (Detert et al, 2000), particularly in terms of developing the necessary commitment to any form of change (Huq and Martin, 2000). In this article we address the need for empirical research examining the link between the TQM approach and organisational culture. Bright and Cooper (1993) pointed to the paucity of empirical and theoretical research examining the relationship between organisational culture and TQM. A decade later Detert et al (2000) made a similar point by suggesting that the relationship between culture and implementation of new behaviours and practices has not been adequately explored. Their work sought to illustrate how eight dimensions that they derived to synthesise the substantive content of a sample of extant organisational culture literature, relate to the specific values and beliefs underlying TQM practice. The need for research in this broad area appears to be current.

This article examines the channels that facilitate the development of a total quality culture based on the findings of an investigation of an international sample of organisations widely regarded as leading exponents of TQM. These are mechanisms or necessary conditions that influence, mould and help sustain a desirable cultural orientation required for a TQM business approach. The organisation of this article is as follows. In the next section we provide a brief overview of perspectives of organisational culture and of the nature of TQM. This provides a foundation for broadly discerning the potential overlap between TQM and culture. Following that we discuss the rationale for the TQM/culture research approach we adopted. A discussion of the research method is followed by examination of the findings of the research, and in the final section we outline our conclusions and identify possible avenues for future research. 


\section{Culture and TQM}

The literature addressing culture is broad, diverse and contradictory. This is reflected in many definitions of culture (Chew and Putti, 1995), and not surprisingly different disciplines define culture differently (Eagleton, 2000). Maull et al (2001) identified four views on culture in the organisational culture literature: as a learned entity, as a belief system, as strategy, and as mental programming (incorporating many elements of the previous three types). Moreover, they argued that it is difficult to make categorical statements about the nature of organisational culture. That is to say, whether organisational culture is an independent or dependent (internal) variable - is organisational culture something an organisation has or is ? Lewis (1996a) concluded from her review of the organisational culture literature, that most authors who explicitly address this question see culture as a variable, which may be affected by both external and internal stimuli, and which may consciously be managed by the organisation itself. Similarly, Detert et al (2000) noted that most empirical work has centred around the view of culture as an enduring, autonomous phenomenon that can be isolated for analysis and interorganisation comparison.

Although there is no true consensus on the definition of organisational culture, an examination of various definitions put forward indicates that some scholars view culture as "shared values", a second group view it as a "way of working", and a third group view it as a combination of "shared values" and "way of working".

Trompenaars and Hampden-Turner (1998), McShane (1998) and Detert et al (2000) position culture as "shared values". Trompenaars and Hampden-Turner (1998) argued that it is a shared system of meanings. It dictates what we pay attention to, how we act and what we 
value. Culture organises such values in "mental programs". Similarly, McShane (1998) saw organisational culture as the basic pattern of shared assumptions, values and beliefs which govern the way employees within an organisation think about and act on, problems and opportunities. Detert et al (2000), quoting O'Reilly and Chatman (1996: 160) focused on culture as "a system of shared values defining what is important, and norms, defining appropriate attitudes and behaviours, that guide members' attitude and behaviours".

Hofstede (1984), described culture as "the way things are done in business", later arguing that symbols, heroes and rituals can be subsumed under the term "practices", because they are visible to an observer (Hofstede et al, 1990). Francesco and Gold (1998) adopted a similar position, asserting that one way to understand an organisation's culture is to ask people how they get work done in an organisation. Nevertheless, Hofstede et al (1990) argued that the core of culture is formed by values. Harris and Johnson (1999) and Williams et al (1993), for example, also occupied this combined integrative position, the former arguing that culture is a learned, socially acquired tradition of a life style of the members of a society, including their patterned, repetitive ways of thinking, feeling and acting. Williams et al (1993) likewise saw culture as "the way we do things around here", or "the way we think about things around here" (cited in Maull et al, 2001). Schein (1996) proposed that an organisation's initial culture is influenced and to a large extent shaped by the organisation's founder. The 'established organisation' then tends to keep and build on the initial behaviour and values. Culture is promulgated through hiring practices, selection processes, orientation of new recruits, development of personnel, training and other corporate activities. These practices would be reinforced by criteria for pay rises and promotion as they reflect the values held by the organisation. Schein (1996) also believes that culture is a learned product of group experience and is, therefore, to be found only where there is a definable group with 
significant history.

Total Quality Management is variously described as a general philosophy of management, a management system, or an organisation's strategic commitment to continuous improvement and meeting the needs of existing and potential customers (Dean and Bowen, 1994; Sirota et al, 1994; Benson, 1992; Frehr, 1997). This accounts for the attention paid to TQM from all sides of commerce and industry and by politicians and academics. Since the early part of the twentieth century, when "management" as a subject first began to be systematically examined (Koontz, 1964), a number of competing management models have emerged in the West. Arguably, the main competing schools which have dominated management theory are the scientific/system-oriented school of management (main proponents Taylor (1947), Fayol (1949), Urwick (1944) and Gulick (Gulick and Urwick (1937)), and the human behaviour/social system school of management (main proponents Barnard (1938), Mayo (1960), Follett (1940), Burns and Stalker (1961) and Woodward (1965)). It is reasonable to argue that TQM in essence is a paradigm of embracing and fusing the strengths of these two competing schools of management thought. TQM's emphasis on processes, measurement, evaluation and review, management and problem solving tools and techniques and management by fact, captures important components of scientific management. On the other hand, concern with employees, leadership, work design and alignment, communication and structural components is consistent with the human behaviour/social system of management (Ghobadian et al, 1998). It would appear therefore that TQM brings together the two dominant models that, to some extent, hitherto have been considered mutually exclusive. Through deductive research Ghobadian and Gallear (1996) proposed the following definition of TQM: 
A structured attempt to re-focus the organisation's behaviour, planning and working practices toward a culture which is employee driven; problem solving; customer oriented; and open and fear-free. Furthermore, the organisation's business practices are based on seeking continuous improvement, devolution of decision-making, removal of functional barriers, eradication of sources of error, teamworking and factbased decision making.

Subsequent research showed that this definition corresponded with leading industrial experts' interpretation of TQM (Gallear, 1999). The available evidence supports the proposition that TQM is a management paradigm that requires certain values, behaviour, and working methods. In essence, it is a way of working.

The above discussion highlights both the distinction and commonality between culture and TQM. Clearly there is overlap between the two concepts. Figure 1 (parts a. to d.) illustrate the overlap in terms of four views of culture presented earlier in this section. Firstly, it is reasonable to argue that TQM is a tool for both changing and forming organisational culture. Moreover, TQM itself appears to have its own set of values which relate to organisational culture. However, it is also a tool for changing an organisation's values, in the direction of the values that it - TQM - expounds. Put another way, TQM comprises a set of values that are underpinned by activities. Lewis (1996a) noted that while TQM has a separate origin from the culture movement, the two fields have converged with the idea that to achieve "excellence" and "quality" it is necessary either to change or work with the culture of an organisation. Boaden and Dale (1994) pointed out that the increased emphasis on customers and their needs make some form of culture change a must for most organisations. Broad agreement for Lewis's and Boaden and Dale's suggestion is provided by Science and 
Engineering Policy Studies Unit (1994) and van Donk and Sanders (1993). Kotter and Heskett (1992) argued that culture is the result of the management process, thus reversing the cause and effect relationship. They too argued that culture is composed of two elements: values and behavioural practices.

\section{$<$ Figure $1>$}

It is generally agreed that the influence of culture on an organisation is powerful and pervasive. It is recognised by many as the "glue" ((Golden, 1992; Smircich, 1983) cited in Detert et al, 2000) that holds an organisation together and as a major contributing factor to an organisation's ability to adapt to its external environment and survive within it. Therefore, any tool that can help an organisation to form its culture or change its culture to a desired state are inherently important. TQM, as argued above, is such a tool.

\section{Emergent research questions and the research perspective}

The authors concur with the view expressed by Maull et al (2001) that, in practical terms, it is difficult to envisage the type of initiative or project which would or realistically could directly aim at changing an organisations' culture. The perspective we take in this research is grounded in practical utility. Our view is that if practising managers believe that the TQM values represent the right culture orientation for their organisation, it is important to establish based on evidence from expert practitioners what are the tangible channels that nurture and progressively facilitate the development of the total quality ethos. The TQM literature supports the proposition that a change in culture is necessary in order to make the organisational change permanent (Saraph and Sebastian, 1993; Sinclair and Collins, 1994; 
Kim et al, 1995; Huq and Martin, 2000; Maull et al, 2001). Moreover, that regardless of the actual culture, in order to change the culture an organisation needs a set of channels that facilitate the change (Whittle et al, 1992; Harber et al, 1993; Saraph and Sebastian, 1993; Bardoel and Sohal, 1999).

A cursory examination of the variables used within a number of non-prescriptive contributions (for example McNabb and Sepic, 1995; Bardoel and Sohal, 1999; Detert et al, 2000; Claver et al, 2001), in conjunction with a brief examination of the anecdotal/prescriptive literature in this area (for example Kim et al, 1995; Thompson, 1998; Tata and Prasad, 1998), suggests that appropriate and pertinent channels through which a culture conducive to TQM can be shaped are:

- $\quad$ teamwork;

- $\quad$ training and development;

- interdepartmental co-operation;

- channels that increase the level of trust within the organisation and

- $\quad$ channels that help clarify goals and objectives across the organisation.

This empirical study has specifically attempted to discern the channels that facilitate organisational culture change as part of the TQM approach. Lewis (1996b) noted that while much of the literature on culture change deals with pitfalls (inhibitors), there is very little on the facilitators - information that managers would find just as useful. Moreover, whilst there exist a number of conceptual and empirical studies contributing to the TQM/organizational culture debate (for example: Huq and Martin, 2000; Buch and Rivers, 2001; Tuckman, 1994; Detert et al, 2000; Edwards et al, 1998 and Wilkinson et al, 1997) the literature to date 
appears not to have attempted to distinguish between the relative importance of the culture shaping channels based on the experience/opinion of a large sample of expert practitioners.

\section{An empirical investigation}

The objectives of the research presented in this paper were:

(a) to discern the channels that facilitate organisational culture change in the context of a total quality management business approach; and

(b) to establish the relative importance of these channels.

It is important to clarify at this juncture that it was not the purpose of this research to revisit questions relating to the 'content' or 'principles' of TQM (many other studies have tackled this area, for example Mann and Kehoe, 1994; Porter and Parker, 1993; Wilkinson et al, 1995; McAdam and Leonard, 2001), nor was it the purpose of this research to attempt to identify the meaning of, or the constructs of, organisation culture (again, and as alluded to in the previous sections, other studies have tackled this area). Rather, the research focuses solely on the channels or necessary conditions that influence, mould and help sustain a desirable cultural orientation required for a total quality management business approach. That is to say, the focus of this research resides at the intersection, or overlap, of the two concepts. The following section describes the empirical research undertaken.

\section{Method of investigation}

The primary data used in the investigation were collected via a structured postal 
questionnaire as part of a much broader modified Delphi study of TQM. The domain of the primary data was confined to organisations recognised as leading exponents of TQM. The rationale for this restriction was straightforward. Supported by examination of methodological shortcomings of previous TQM research investigations it was concluded that a great deal more could be learnt from organisations that had achieved a high level of TQM success than from those organisations that had either failed or made little progress. Thus, invitation to participate in the investigation was based on fulfilment of at least one of the following criteria considered to indicate a successful total quality organisation:

- was a past winner, finalist or recipient of certificate of merit from an internationally recognised quality award scheme (European Quality Award, Malcolm Baldrige National Quality Award (USA), Canadian Awards for Business Excellence (Total Quality Category) or Australian Quality Award);

- had been awarded a peer acknowledged quality rating by major customers or vendors; and/or

- had received recognition through prestigious professional or academic journals as a total quality organisation.

Simply being a member of a recognised quality institution or foundation was not deemed to guarantee the degree of TQM best practice required for this investigation. The literature also indicated that TQM practice in 'not-for-profit' organisations was largely in its infancy and as such under-developed, and therefore the investigation was restricted to the analysis of 'forprofit' organisations. The target sample was constructed and comprised fifty-one benchmark organisations. The single point of contact (respondent) at each organisation was the Quality Director / Corporate Quality Officer or equivalent post. 
Given the potential for inconsistency of interpretation from an open-ended questioning strategy, the pre-defined investigative approach was preferred. Figure 2 illustrates the process used for derivation of the study variables, hereafter referred to as necessary conditions, for simplicity. Starting with some basic notions about the conditions that must exist in an organisation for a total quality ethos to permeate, the authors employed focus group discussion to generate an extensive list of proposed necessary conditions in the form of short statements. The focus group members were drawn from colleagues with considerable practical and academic experience of total quality organisations.

\section{$<$ Figure $2>$}

An extensive literature review was used to refine the list. The literature review was broad and wide-ranging in the TQM field, but paid particular attention to two aspects. Firstly, examination of non-prescriptive literature dealing with culture and TQM (for example Harber et al, 1993; van Donk and Sanders, 1993; Science and Engineering Policy Studies Unit, 1994; Tuckman, 1994; Emery et al, 1996; Morrow, 1997; Bardoel and Sohal, 1999). Secondly, examination of non-prescriptive literature dealing with difficulties encountered in implementing and sustaining TQM (for example Wilkinson et al, 1992; Longnecker and Scazzero, 1993; Wilcox et al, 1996; Dale et al, 1997; Zabada et al, 1998; Yong and Wilkinson, 1999). The findings generated from these two consecutive processes resulted in a list comprising of fifteen statements that were converted into a research instrument using a five-point Likert scale. The research instrument was independently screened and verified by a committee of five other known and experienced TQM practitioners from industry and commerce not in the study sample. They were asked to comment on the relevance, validity, 
comprehensiveness and clarity of the research instrument, and adjustments were made where necessary. The final research instrument comprised fifteen necessary conditions.

\section{Findings}

Participants were asked to indicate how important their organisation viewed each necessary condition on the Likert scale (5=very important; $4=$ important; $3=$ neutral; $2=$ not very important and $1=$ not important at all). Participants were also invited to add to the list any other necessary conditions which their organisation viewed as essential for the attainment of an organisation-wide quality ethos.

Useable responses were collected from forty-seven of the fifty-one benchmark organisations. Twenty-two of these organisations operated in the manufacturing sector, twelve operated in the service sector and thirteen considered themselves to have a dual manufacturing and service business orientation. In terms of size, thirty-three were classified as large organisations and fourteen as small to medium-sized enterprises ${ }^{1}$. The organisations' experience of TQM, that is since the commencement of their TQM implementation processes, ranged from three to thirteen years, with an average for the sample of 6.75 years.

Mean values for each proposed necessary condition were calculated. The response confirmed that fourteen of the fifteen proposed necessary conditions were considered to be channels that facilitate organisational culture change in the context of a total quality management business

\footnotetext{
${ }^{1}$ In this study the authors adopted the firm size classification used by Eurostat (EC-Directorate General): micro organisations (0-9 employees), small to medium-sized organisations (10-499 employees) and large organisations (+500 employees).
} 
approach. Moreover, the findings confirmed that not all fourteen were of equal importance. Figure 3 shows the calculated mean values for the fifteen necessary conditions in descending rank order. Six necessary conditions were perceived to be very important (value range: mean $\geq 4.5$ ) and eight were perceived to be important (value range: $3.5 \leq$ mean $<4.5$ ).

\section{$<$ Figure $3>$}

Very important necessary conditions

Three of the six necessary conditions rated as very important directly concerned the top management of the organisation. These were:

- $\quad$ leadership and vision from the top,

- $\quad$ active and visible participation of top management, and

- $\quad$ commitment to and promotion of the TQM concept by the Chief Executive to all levels of the organisation.

These findings indicate that the provision of the appropriate cultural norms, values and beliefs that underpin an organisation-wide total quality ethos, or at the very least the responsibility for nurturing these norms, values and beliefs, is the obligation of the organisation's top management. They suggest that although it is their immediate supervisors and peers that employees interact with on the more regular basis, top management perspectives can have a potentially greater influence on the organisation as a whole. Klein et al (1995) argued that leaders are integral to the formation of culture norms and values as perceived by employees. Creating the vision is considered to be important because it gives an organisation a sense of purpose, and enables the organisation to be pulled forward by its 
future, rather than be driven by its past. At the apex of the organisation, top management should be the most visible single entity to the rest of its members. Zairi (1994) suggested that leading the development and communication of the vision is very critical since TQM's workings often follow a bottom-up approach and, unless there is corporate ownership, performance is unlikely to ensue or be sustained. However, experience would suggest that if the vision is to truly unite and focus employees on where the organisation is heading, its communication has to reach everyone in the organisation (Zairi, 1994). Furthermore, as Dale and Cooper (1994) noted, an organisation needs a means of providing continuity in order for it to hold the gains - again, at the apex of the organisation, top management have the greatest range of visibility across the organisation, and hence hold the pivotal position for providing the continuity.

The importance attached to active and visible participation of top management, indicates that the influence of their own behaviour - setting the example - is not lost on the senior management of benchmark TQM organisations. Furthermore, the importance of top management commitment to TQM, their promotion of TQM and their participation cannot be stressed highly enough (Ugboro and Obeng, 2000; Sila and Ebrahimpour, 2003; Prajogo and Sohal, 2004; Taylor and Wright, 2003). Ugboro and Obeng's (2000) study findings suggested a strong and active role for top management in creating an organisational culture that promotes total quality. Research has also shown that failures to either successfully introduce TQM into organisations, or failure to sustain the TQM momentum (and thus establish a permanent quality ethos), more so than any other influencing factors can be traced back to lack of commitment on the part of senior management as a primary source or catalyst for the breakdown (Lascelles and Dale, 1990; Aubrey II, 1993; Beer, 2003). Strebel (1996) argued that alignment between an organisations statements and management's behaviour is 
the key to creating a context that evokes employee commitment - management's credibility, once lost, is difficult to recover. More recent debate surrounding the nature of employee commitment and involvement is presented later in this paper. Nevertheless, Buch and Rivers (2001) case evidence illustrates that high levels of commitment and support from the leadership are not always achieved in the eyes of employees. Their findings did however support the proposition that employees who perceive leadership as more committed and supportive would also perceive TQM values as more integrated into the organizations culture, thus arguing for the strong influence of leadership on the successful integration of TQM values and practices into the culture. Beer (2003) argued that TQM failure occurs because senior management tend to motivate change through top-down programmes and fail to solicit and receive feedback about potential gaps between their TQM rhetoric and the reality of implementation, which in turn prevents them from learning how their actions and policies may be responsible for the gap and then making changes accordingly. Beer (2003) argues that:

“the TQM transformation will persist only if top management requires and ultimately institutionalizes an honest organisation-wide conversation that surfaces valid data about the quality of management .... and leads to changes in management quality or replacement of managers."

To this end, Beer (2003) offers a set of empirically validated principles for developing a high 'quality of management' at every level of the organization.

The concept of 'commitment' featured three times within the necessary conditions that were rated by the leading exponents to be very important. The first instance related to senior management as discussed above. The second and third instances of 'commitment' related to all of an organisation's employees. These were: 
- $\quad$ involvement of, and commitment from all employees, and

- $\quad$ all employees dedicated to continuous (process / working practice) improvement.

The necessary condition all employees dedicated to continuous (process / working practice) improvement represents a proactive orientation where processes and working practices are in a state of continuous development (Hayes, 1997) and everyone in the organisation is involved in contributing to this development. This is in contrast to the "steady-state" model (Hayes, 1997), where any improvements to processes or working practices tend only to be undertaken as a consequence of reactions to problems encountered. Involvement generally refers to the practice of allowing employees to have a strong input into operational decisions directly affecting their and the organisation's work, and delegating responsibility for aspects of that work to them (Cole et al, 1993; and Van Aken et al, 1994; Nelson Joseph et al, 1999). It is logical to argue that involvement and commitment have a bi-directional relationship. Because involvement increases the interdependency of employees and hence their responsibility to others, for widespread involvement to take root effectively widespread commitment is required. Conversely, a positive employee response to the facilitation of involvement can generate commitment. Oliver (1990, cited in Snape et al, 1995) proposed that employee commitment can be generated through the introduction of performance indicators to clarify accountabilities, involving and empowering employees to increase their sense of volition, and the removal of quality control inspection. Interestingly, Edwards et al's (1998) study found that favourable views on quality were strongest where the monitoring of employees was the most intense. A broad examination of the literature addressing involvement in the context of TQM (for example Van Aken et al (1994); Ahire, 1996; Nelson Joseph et al, 1999) indicates that the following are amongst the core positive influences and outcomes of widespread involvement, as were succinctly outlined by Cole et al (1993). 
Firstly, the enactment of involvement leads to self-realisation and human dignity, thereby positively influencing employee motivation. As Cole et al (1993) explained, the impact of involvement on motivation is based on the sound behavioural principle that those involved in work processes will more enthusiastically implement changes that they themselves have designed. Secondly, involvement provides the opportunity for goal agreement (Cole et al, 1993). It provides a mechanism through which individual and organisational goals and objectives can be aligned. Sathe (1983) pointed out that employees feel a sense of commitment to an organisation when they can identify with goals and objectives and experience some emotional attachment to them. Thirdly, with an emphasis on interpersonal process, involvement emphasises human process skills such as communications, teamwork and conflict resolution - these are skills that improve the quality of decision making and enhance employee "buy-in" (Cole et al, 1993). Fourthly, as Cole et al (1993) further pointed out, by making lower level employees responsible for maintaining and improving their work processes, involvement releases managerial and technical personnel from the commonplace fire-fighting activities for more purposeful activities. Conversely, comprehensive and grassroots involvement in problem solving would allow organisations to move the "distribution of intelligence" downward in the organisation, bringing increased information and capability in local problem solving without involving costly middle-managers who may contribute to information distortion. Finally, when people feel a sense of commitment and are involved, they tend, in making decisions and taking action, to evaluate the alternatives in terms of their impact for the organisation, rather than for themselves (Sathe, 1983). These influences and outcomes would appear to support Cole et al's (1993) assertion that by allowing all employees to make substantial contributions to improving work performance, involvement has the potential to unleash a great competitive force. Evidence from Corbett and Harrison (1992) appears to provide strong support for this latter assertion. 
It is suggested that involvement in practice means teamworking, task-based participation, process improvement, problem solving meetings, suggestion schemes and appraisal schemes (Wilkinson et al, 1997; Edwards et al, 1998; Silos, 1999) in addition to involvement in goal setting, and moreover could include involvement in selection of new recruits, and a shift towards cell organization (Snape et al, 1995). More broadly, Ugboro and Obeng (2000) found that employee involvement is facilitated by employee satisfaction with communication at lower organizational levels, availability of job requirement information, enhanced promotion and development opportunities, and availability of information about the organisation's values, vision, and strategies. They further argued that:

“employee satisfaction with the organisation's reward and recognition systems, organizational adjustment to a total quality culture, training and re-training programs that facilitate continuous improvement, and health and safety provisions in the job environment facilitate employee involvement and participation in TQM programs”.

There has however been much debate on the nature of employee involvement in the TQM approach, and particularly involvement's capacity to either lessen or heighten managerial control of employees. Both Wilkinson et al (1997) and Edwards et al (1998) have brought attention to the tendency for the TQM debate to be conducted between two camps: the proponents and the critics, although recognising that more recent analysis has been more balanced, with a third intermediate position having emerged - the context dependent view (Edwards et al, 1998). The proponents, they argue, see it as improving competitive advantage and at the same time empowering the workforce by delegating responsibility to those carrying out the task. To its critics however, it represents tighter managerial control, increased intensification of work and increased surveillance. The view of involvement under 
TQM being unequivocally good and beneficial to all parties (Wilkinson et al, 1997) is therefore not universally accepted. Empirical evidence at non-management level supports this viewpoint. Wilkinson et al (1997), for example, report the limited nature of employee involvement under TQM derived from their research evidence from six manufacturing companies and point to the variation in employee involvement which is found in practice. They argued that employee involvement can take on different forms with the degree of involvement and extent of implementation by management varying greatly. They cautioned therefore that because employee involvement under TQM has a complex and multidimensional nature, analyses need to be tempered by an understanding of the vast variation that occurs in different organizations.

Teamwork was considered to be a very important necessary condition. Teamwork is a work arrangement that arguably has the capacity to enable cooperation and effective individual involvement and it represents a way of working. Team activity provides a strategy for integrating work involving highly interdependent tasks (Cole et al, 1993). Employees working in teams cultivate and negotiate positive assumptions, which help them individually and collectively to operate effectively. Furthermore, placing overall responsibility with teams alleviates the potential for individual blame (Wilkinson, 1992). According to Hayes (1997), teamwork encourages people to be more professional in their approach and to take their responsibilities seriously. Teamwork is also an important condition for continuous improvement (Coyle-Shapiro, 1995). Klein et al (1995), from their cross-sectional study, concluded that encouraging teamwork lead to favourable perceptions of employee control and quality outcomes. Rees (1999) found strong employee support for teams and that employees felt that teamworking allowed them to have more input into problem-solving and decision making. However, Rees' case evidence also indicated that the actual levels of 
discretion and responsibility afforded to teams (of two types: task-based and problem solving) was low, leading Rees to conclude that in these settings what had occurred was actually a reorganisation of control - a general increase in the level of employee involvement, but with general control remaining in the hands of management.

\section{Important necessary conditions}

Eight necessary conditions were perceived to be important. The importance attached to the necessary condition building and maintaining a human environment that allows the members of the organisation to improve quality, continually based on mutual trust and collaboration emphasises the fact that in a TQM environment the essence of the permanent underlying contract between the organisation and its members is mutual trust. Individuals understand that in exchange for their effort and commitment to quality improvement, the company will help them develop their potential (de Geus, 1997). Trust is important because employees and organisations have reciprocal obligations and mutual commitments, both stated and implied, that define their relationship (Strebel, 1996). Trust in colleagues taps two dimensions: a belief that co-workers would assist the individual should the need arise; and an individual's confidence in the ability of his/her co-workers (Coyle-Shapiro, 1995). Arguably, a feeling of trust and dependence between employer and employees, and amongst peers, reinforces mutual expectation and commitment. Despite its perceived importance however, Edwards et al's (1998) findings point to the notion that trust is inherently very context dependent and warns that traditional sources of distrust can affect acceptance of the quality management approach.

The literature repeatedly identifies the importance of organisation-wide congruity of goals 
and objectives in the TQM approach (Schonberger, 1992; Sirota et al, 1994; Butz Jr, 1995; Kennerfalk and Klefsjo, 1995). To this end, policy deployment represents a disciplined organisational goal-setting methodology (King, 1989; Jugulum and Sefik, 1998). Bechtell (1996) argued that policy deployment helps the management of the organisation to ensure that the basic day-to-day processes that support the business are healthy and, at the same time, that the fundamental changes that are necessary for the long-term health of the organisation are occurring. Moreover, the methodology is inclusive of all levels within the organisation, rather than exclusive to a top level function.

It is generally agreed that the TQM approach calls for continuous improvement in the eyes of the customer. Since the "customer" is in the next work-centre, department, site or company, organisational and physical boundaries must be breached (Schonberger, 1994). The internal customer/supplier relationship concept reflects a notion that all employees in the organisation provide a service, not only to the external customer but also to their colleagues, and therefore, the customer is anyone for whom a service is rendered - both inside and outside the organisational boundaries (Rodrigues, 1994). Recent empirical analyses of the internal customer/supplier concept in TQM context appear to be absent. Stauss (1995) however, argued that the concept only makes sense for workflow (interactions between [departments] which are linked in a work-flow) and audit/advice services, while evaluation/audit relationships do not comprise any kind of customer-supplier relationship. Moreover, Stauss (1995) stressed that the internal customer orientation does not arise automatically but results from management decisions which bring about an appropriate setting.

Two of the important necessary conditions concerned collaborative arrangements with external stakeholders. These were: 
- $\quad$ appropriate partnerships between your organisation and your customers, and

- $\quad$ appropriate partnerships between your organisation and your suppliers.

The importance attached to appropriate partnerships between your organisation and your customers indicates that benchmark TQM organisations prefer to operate a transactional approach which seeks to move customer relationships, where appropriate, from a series of disconnected customer-led transactions into partnerships that involve direct collaboration, bringing the organisation and employees much closer to the customers' requirements, expectations and ultimately perceptions of performance. Mehra et al (2001) argue that:

"This closeness should take the form of an enterprise wide sharing of ideas, actions and other planning aspects. Essentially it boils down to a business "virtually" sitting at the door of the customer."

This modification to the relationship would appear to be important for a number of reasons. Firstly, customers often do not know themselves 'exactly' what they want from a product/service package, and therefore cannot readily provide the organisation with accurate information about their requirements through conventional methods (Ackoff, 1993). The closeness involved in a partnership enables the customer to be an active participant in the design of the product/service package. Secondly, it is becoming increasingly important to pay serious attention to customers perceptions of the organisation's product/service package, as to the tangible transactions. Thirdly, customers now tend to seek continual improvement in their transactions with their suppliers (Hoyt and Huq, 2000; Moller et al, 2003). Creating the opportunity to visibly demonstrate competence and/or performance improvement to customers can have a significantly greater impact than through indirect communication. Finally, even with the greatest effort to satisfy it is inevitable that customer related problems are likely to surface, and it may be argued that there are very few customer related problems 
that an organisation can resolve in isolation. Customer partnership arrangements can help to break down barriers and establish mutual trust, thus making it easier to understand each others' business constraints and turn cause for dissatisfaction into opportunity for mutually beneficial improvement.

Partnerships between an organisation and its suppliers represents a collaborative approach in which the organisation and suppliers work together closely, seeking mutual benefits by sharing the risks and rewards of a cooperative relationship (Ellram and Edis, 1996; Gadde and Snehota, 2000; McHugh, 2003). As Landeros et al (1995) suggested, in competitive environments less tangible factors such as suppliers' basic management philosophy, managerial attitudes towards quality and propensity for collaborative problem solving, can often be more important than specific operational criteria. It has also been suggested that effective customer-supplier partnerships are instrumental in stimulating cross-functional activity within the individual companies (Landeros et al, 1995). The necessary condition emphasised the need for "appropriate" partnerships. Close partnering arrangements requires a high level of analytical, problem solving and creative ability, as well as knowledge of the supplier's production processes (Stuart, 1993; Christopher and Juttner, 2000) and service delivery processes. Ellram and Edis (1996) suggested that as such the intensity of these relationships limits the number that can be managed effectively, and hence most supplier partnering relationships tend to be oriented around specific, relatively important purchased items or services. Interestingly, in the wider management literature, there has been evidence to suggest that in practice limited use is made of partnerships - they are not widespread (McDonald and Dierkes, 1999).

The three other necessary conditions rated as important by the leading exponents were: 
- continuous investment in training, and development of all employees skills,

- quality of the work environment, and

- shared responsibility.

It is reasonable to suggest that if the employees of an organisation are to contribute effectively to the development of the organisation, it is crucially important that they too are provided with the means to develop and acquire necessary skills. Since the business environment is in a constant state of flux, and organisations must pro-actively respond to the changes that occur, continuous investment in training and development of skills to produce a work force that is versatile in normal business operations and able to contribute to both problem solving and continuous improvement would appear to be imperative. Furthermore, continuous investment in training and development of all employees skills is a primary mechanism through which organisations can socialize employees to the desired organisational values (Walton, 1989 (cited in Rodrigues, 1994)) - it is important in signalling the organisation's desire for greater employee involvement, the value the organisation attaches to employee involvement and commitment, and the organisation's reciprocal commitment to increasing the well-being of its employees. As Palmer and Wilson (1995) suggested, without training and the development of employees skills, the choices as to how employees are going to alter their cognitive, affective and behavioural factors are very limited. Klein et al's 1995 study reported that employee development leads to favourable perceptions of employee control and quality outcomes. Edwards et al's (1998) research highlighted the importance of training in enhanced teamworking and quality. They observed a tendency for experience of such training to promote a favourable view of quality programmes. 
It has been reported in the past that in practice training is often treated as an independent step in establishing TQM and that many organizations place far too much reliance on it as the route to securing a quality oriented culture (Sirota et al, 1994; Graves, 1993). The desired effect of training, however, is unlikely to be realized if the opportunity to transfer the newly acquired skills and knowledge to the workplace (Ho et al, 2001) is not provided. Ho et al (2001), for example, reported based on the findings of their study that the effective use of quality data, timely reporting of quality performance, and implementation of new supplier quality management practices were indispensable to the successful transfer of TQM training, and that adjustments to job design should also be considered.

Quality of the work environment refers to the existence of a consultative and open rather than directive approach to working practice within the organisation, in which information is made readily available, staff are encouraged to question and participate in debates, and mistakes are viewed and used as a part of the learning process and are not punished. People need timely accurate information in order to make decisions which influence the quality of their work (Nelson Joseph et al, 1999). The authors would suggest that the importance assigned to the necessary condition quality of the work environment suggests that employee perceptions of a work environment unsympathetic to openness and learning will result in creation of a permanent psychological barrier, to the detriment of continuous improvement working practices and quality related orientations. Under such conditions, employees may find it difficult to justify their commitment and contribute whole-heartedly to the production of quality products and services, or to the improvement of the business operations.

Alternatively, if employees are provided with a high quality, sympathetic work environment they would be significantly more likely to accept, welcome and embrace challenge and responsibility. 
The concept of shared responsibility, considered to be an important necessary condition, has indirectly been explicated throughout the preceding discussion. In fact, it may be argued that shared responsibility is a characteristic of, or is consequential on the other necessary conditions. Discussion on the importance (or limits) of shared responsibility will not be repeated here. However, it is important to note that the fundamental significance of shared responsibility is that it represents the removal of the 'them-and-us' attitudinal and behavioural barriers that can plague organisational effectiveness. It also fosters teamwork, participation and commitment to the well being of the social group and hence to the organisation.

\section{Of neutral importance}

One necessary condition was considered to be of neutral importance as a channel that facilitates organisation culture change in the context of a TQM approach - involvement in the community. This finding indicates that whilst involvement in the community may re-enforce employees' perception of a caring organisation thus helping to secure their commitment, in addition to creating a positive perception in the eyes of external stakeholders, it is not a significantly necessary contributor for enabling a total quality ethos to permeate the organisation.

\section{Implications of the findings}

Sustainable TQM practice, according to our sample of leading exponents of the practice, requires two main foci:

Firstly, the focus should be on providing leadership and vision from the top management, 
ensuring active and visible participation of top management, and ensuring commitment to and promotion of the TQM concept by the Chief Executive to all levels of the organisation.

Secondly, the focus should be on the mobilisation of all employees around the goal of continuous improvement and enlisting their active commitment and involvement, and the findings indicate prevalence of teamwork is an important facilitating mechanism to this end.

The six necessary conditions rated as very important by the leading exponents of TQM largely express desired "attitudes" and "behaviours". The necessary conditions rated as important may be regarded as "supporting" necessary conditions in the sense that they help to underpin the organisation's ability to put in place and sustain the "attitudes" and "behaviours" represented by the very important necessary conditions. In contrast therefore, they represent supporting practices in the form of internal operational facilitators and external collaborative facilitators. They are important to moulding and sustaining a desirable cultural orientation, but, based on the evidence from leading exponents, cannot replace or at any time substitute for the leadership and commitment oriented channels. The latter must take precedent.

Despite the rigour of the systematic process employed to identify and verify the variables tested in this study, there are other facilitating channels that our process did not highlight and in this paper we are not claiming that that we have arrived at a truly comprehensive and all encompassing set of facilitating channels. For example, Edwards et al's (1998) study which undertook to determine employee responses to TQM, using evidence from six case 
companies that could not be classified as leading edge examples, found that two conditions for success in quality programmes stood out, namely notably high job security and a cooperative relationship with trade unions. The anomaly between Edwards et al's (1998) and our findings could potentially be explained by the differences in samples targeted, size of samples, respondents and the different research methods employed. Our process involving focus group of experts, triangulation with the literature and verification by experienced practitioners identified fifteen channels for further empirical testing and the two factors specified by Edwards et al (1998) did not feature.

\section{Conclusions and future research directions}

Total quality management has emerged, and despite some criticism remains, a prevalent management concept. Furthermore, the positive contribution that TQM can make to industrial and commercial organisations competitive stance is generally recognised. On the one-hand, in the recent past a large and increasing number of organisations have attempted to adopt TQM in recognition of the strategic importance of, and their commitment to, the management of quality. On the other hand, there appears to be a large contingent of organisations who believe they already have a TQM approach in place. It is apparent in both cases however, that many organisations are misunderstanding and mis-applying TQM (Reger et al, 1994; Eskildson, 1995; Redman and Grieves, 1999; Bacdayan, 2001; Kanji and Moura e $\mathrm{Sa}, 2003)$. A careful review of the literature confirms that despite the interest TQM remains an imprecise subject (Hill and Wilkinson, 1995). Culture is also considered by many scholars as a key contributor to success. In this paper we argued, with the help of the extant literature, that there are significant overlaps between culture and the TQM concept. In fact the outcome of this research confirms the existence of significant overlap between culture and TQM. A 
list of factors underpinning the successful development and implementation of TQM was developed with the help of experts. The veracity of these facilitating channels was confirmed through extensive literature review and a committee consisting of five experienced and leading practitioners of TQM. Table 1 shows the relationship between these channels and prevalent views of culture.

There is broad agreement that the successful adoption and practice of a TQM business management approach requires close attention, and more often that not modification, to organisational culture. Table 1 confirms the veracity of this widely held belief. Yet culture itself is somewhat intangible, and regardless of the precise cultural aspirations, in order to change and maintain the desired culture organisations need a set of facilitating channels. TQM propagates a set of values - a culture - and if an organisation believes that the TQM culture is the right culture for it, then it is important to understand what are the channels that facilitate its development. The research described in this paper set out to systematically identify the necessary conditions (channels) that influence, mould and sustain a desirable cultural orientation required for a total quality management business approach. It has attempted to respond to the need for empirical research examining the link between the TQM approach and organisational culture. Based on data gathered from a sample of forty-seven leading exponents of TQM approach and ethos, a set of fourteen necessary conditions - the channels - have been identified and the relative importance amongst them has been established.

The discussion of, and illustration of the ongoing debates relating to the empirical findings presented in this paper is by no means claimed to be exhaustive. We have sought to provide rational arguments explaining the importance attached to the fifteen necessary conditions, and 
to highlight findings of other closely related research. Moreover, the authors recognise that the fourteen necessary conditions identified as very important or important may potentially not be wholly sufficient in every case of TQM introduction. However, the in-depth and systematic approach employed to identify and verify the study variables to be tested suggests that collectively these fourteen channels represent a cohesive, complimentary and comprehensive foundation for facilitating the culture change that is necessary.

The authors' observations correspond with that made by Sitkin et al in 1994 and which to date appears to remain highly legitimate, that there is concern that the potential contribution of TQM may be lost if its theoretical underpinnings are not critically assessed. We recognise that the necessary conditions identified as very important are not necessarily new to the TQM literature. However, responding to the aforementioned concerns requires accumulation of empirical evidence systematically derived from rational perspectives and that can provide the basis for confirmation or otherwise. The authors contend that, given the central role of organisational culture in the TQM approach, and moreover in advancing and shaping organisations' short, medium and long term destiny, this contribution addresses, in part the concerns expressed.

In practical terms, the findings of the study increase understanding of where, and how, in an organisation, culture reveals and asserts itself and moreover of the channels that facilitate effective functioning of an organisation's total quality approach. It is hoped that this understanding can be useful to practising managers, leading to more effective efforts at achieving an organisation-wide total quality ethos. The research contributes an empirically derived set of fourteen facilitating channels that can act as a base-line from which the existing cultural orientation in organisations seeking a TQM approach and ethos may be critically 
examined or evaluated.

The findings provide a basis for further empirical or conceptual work on culture in the TQM setting and, more generally for the discipline of total quality management. For example through subjecting the findings to further empirical examinations for verification, and in particular employing longitudinal research design to examine the link between TQM culture facilitators and successful operational outcomes. 


\section{References}

ACKOFF, R.L. (1993) Beyond total quality management, Journal for Quality and Participation, 16(2), pp. 66-78.

AHIRE, S. (1996) TQM age vs quality: an empirical investigation, Production and Inventory Management Journal, 37(1), pp. 18-23.

AUBREY II, C.A. (1993) Should the board of directors be involved in TQM?, National Productivity Review, 12(3), pp. 317-323.

BACDAYAN, P. (2001) Quality improvement teams that stall due to poor project selection: an exploration of contributing factors, Total Quality Management, 12(5), pp. 589-599.

BARDOEL, E.A. \& SOHAL, A. (1999) The role of the cultural audit in implementing quality improvement programmes, International Journal of Quality and Reliability Management, 16(3), pp. 263-276.

BARNARD, C. (1938) The Functions of the Executive (Cambridge MA, Harvard University Press).

BECHTELL, M. (1996) Navigating organizational waters with Hoshin Planning, National Productivity Review, 15(2), pp. 23-42.

BEER, M. (2003) Why total quality management programs do not persist: the role of management quality and implications for leading a TQM transformation, Decision Sciences, 34(4), pp. 623-642.

BENSON, T.E. (1992) IQS: quality is not what you think it is, Industry Week, 241(19), pp. 22-34.

BOADEN, R.J. \& DALE, B.G. (1994) A generic framework for managing quality improvement: theory and practice, Quality Management Journal, 1 (4), pp. 11-29. 
BRIGHT, K. \& COOPER, C.L. (1993) Organizational culture and the management of quality: towards a new framework, Journal of Managerial Philosophy, 8(6), pp. 21-27.

BUCH, K \& RIVERS, D. (2001) TQM: the role of leadership and culture, Leadership \& Organization Development, 22(8), pp. 365-371.

BURNS, T. \& STALKER, G. (1961) The Management of Innovation (London, Tavistock Publishers).

BUTZ JR, H.E. (1995) Strategic planning: the missing link in TQM, Quality Progress, May, pp. $105-108$.

CHEW, I. K. \& AND PUTTI, J. (1995) Relationship on work-related values of Singaporean and Japanese managers in Singapore, Human Relations, 48(10), pp. 1149-1170.

CHRISTOPHER, M. \& JUTTNER, U. (2000) Developing strategic partnerships in the supply chain: a practitioner perspective, European Journal of Purchasing and Supply Management, 6, pp. 117-127.

CLAVER, E., GASCO, J., LLOPIS, J. \& GONZALES, R. (2001) The strategic process of a cultural change to implement total quality management: A case study, Total Quality Management, 12(4), pp. 469-472.

COLE, R.E., BACDAYAN, P. \& WHITE, B. J. (1993) Quality, participation, and competitiveness, California Management Review, Spring, pp. 68-81.

CORBETT, L. \& HARRISON, N. (1992) Manufacturing performance and employee involvement: a study of factors influencing improvement, International Studies of Management \& Organisation, 22(4), pp. 21-32.

COYLE-SHAPIRO, J. (1995) The impact of a TQM intervention on teamwork: a longitudinal assessment, Employee Relations, 17(3), pp. 63-74. 
DALE, B.G. \& COOPER, C.L. (1994) Introducing TQM: the role of senior management, Management Decision, 32(1), pp. 20-26.

DALE, B.G., BOADEN, R.J., WILCOX, M. \& MCQUATER, R.E. (1997) Sustaining total quality management: what are the key issues?, The TQM Magazine, 9(5), pp. 372-380.

DE GEUS, A. (1997) The living company, Harvard Business Review, March-April, pp. 5159.

DEAN, JR, J.W. \& BOWEN, D.E. (1994) Management theory and total quality: improving research and practice through theory development, Academy of Management Review, 19(3), pp. 392-418.

DETERT, J.R., SCHROEDER, R.G. \& MAURIEL, J.J. (2000) A framework for linking culture and improvement initiatives in organizations, Academy of Management Review, 25(4), pp. 850-863.

EAGLETON, T. (2000) The Ideas of Culture (Oxford, Blackwell Publishers).

EDWARDS, P., COLLINSON, M. \& REES, C. (1998) The determinants of employee responses to total quality management: six case studies, Organization Studies, 19(3), pp. 449475 .

ELLRAM, L. \& EDIS, O. (1996) A Case study of successful partnering implementation, International Journal of Purchasing and Materials Management, 32(4), pp. 11-19.

EMERY, C.R., SUMMERS, T.P. \& SURAK, J.G. (1996) The role of organizational climate in the implementation of total quality management, Journal of Managerial Issues, 8(4), pp. 484-496.

ESKILDSON, L. (1995) TQM's role in corporate success: analysing the evidence, National Productivity Review, Autumn, pp. 25-38. 
FAYOL, H. (1949) General \& Industrial Management (London, Pitman).

FOLLETT, M.P. (1940) Dynamic Administration: The Collected Papers of Mary

Parker Follett, Ed. H. C. Metcalf and L. Urwick (New York: Harper \& Brothers Publishers).

FRANCESCO, A.M. \& GOLD, B.A. (1998) International Organizational Behavior: Texts, Readings, Cases and Skills (New Jersey, Prentice Hall).

FREHR, H.U. (1997) From ISO 9000 to total quality management, a rough road, Human Systems Management, 16(3), pp. 185-193.

GADDE, L. \& SNEHOTA, I. (2000) Making the most of supplier relationships, Industrial Marketing Management, 29(4), pp. 305-316.

GALLEAR, D.N. (1999) Developing a theory of Total Quality Management: using the Delphi technique, unpublished $\mathrm{PhD}$ thesis, Middlesex University.

GHOBADIAN, A. \& GALLEAR, D.N. (1996) Total quality management in SMEs, Omega The International Journal of Management Science, 24(1), pp. 83-106.

GHOBADIAN, A., GALLEAR, D., WOO, H. \& LIU, J. (1998) Total quality management impact, introduction and integration strategies (London: CIMA Publishing).

GOLDEN, K.A. (1992) The individual and organizational culture: Strategies for action in highly-ordered contexts, Journal of Management Studies, 29, pp. 1-21.

GRAVES, D. (1993) Forget the myths and get on with TQM - fast, National Productivity Review, 12(3), pp. 301-311.

GULICK, L.H. \& URWICK, L.F. (Eds.) (1937) Papers on the Science of Administration (Columbia University Press). 
HARBER, D., BURGESS, K. \& BARCLAY, D. (1993) Total quality management as a cultural intervention: an integrative review, International Journal of Quality \& Reliability Management, 10(6), pp. 17-27.

HARRIS, M. \& JOHNSON, O. (1999) Cultural Anthropology (Allyn and Bacon).

HAYES, N. (1997) Successful Team Management (London, International Thompson Business Press).

HILL, S. \& WILKINSON, A. (1995) In search of TQM, Employee Relations, 17(3), pp. 8-25.

HO, D.C.K., DUFFY, V.G. \& SHIH, H.M. (2001) Total quality management: an empirical test for mediation effect, International Journal of Production Research, 39(3), pp. 529-548.

HOFSTEDE, G. (1984) Cultures Consequences: International Differences in Work-Related Values (Beverly Hills, Sage Publications).

HOFSTEDE, G., NEUIJEN, B., OHAYV, D. \& SANDERS, G. (1990) Measuring organizational culture: a qualitative and quantitative study across twenty cases, Administrative Science Quarterly, 35, pp. 286-316.

HOYT, J \& HUQ, F. (2000) From arms-length to collaborative relationships in the supply chain, International Journal of Physical Distribution and Logistics Management, 30(9), pp. $750-764$.

HUQ, Z. \& MARTIN, T.N. (2000) Workforce cultural factors in TQM/CQI implementation in hospitals, Health Care Management Review, 25(3), pp. 80-93.

JUGULUM, R. \& SEFIK, M (1998) Building a Robust Manufacturing Strategy, Computers and Industrial Engineering, 35(1/2), pp. 225-228.

KANJI, G. \& MOURA E SÁ, P. (2003) Sustaining healthcare excellence through performance measurement, Total Quality Management \& Business Excellence, 14(3), pp. 
269-290.

KENNERFALK, L. \& KLEFSJO, B. (1995) A change process for adapting organizations to a total quality management strategy, Total Quality Management, 6(2), pp. 187-197.

KIM, P.S., PINDUR, W. \& REYNOLDS, K. (1995) Creating a new organizational culture: the key to total quality management in the public sector, International Journal of Public Administration, 18 (4), pp. 675-709.

KING, B. (1989) Hoshin* Planning: The Developmental Approach (Meuthen, MA, GOAL/QPC).

KLEIN, A.S., MASI, R.J. \& WEIDNER, C.K. (1995) Organization culture, distribution and amount fo control, and perceptions of quality, Group \& Organization Management, 20(2), pp. 122-148.

KOONTZ, H. (Ed.). (1964) Toward a Unified Theory of Management (New York, McGrawHill).

KOTTER, J.P. \& HESKETT, J.L. (1992) Corporate Culture and Performance (New York, Free Press).

LANDEROS, R., RECK, R. \& PLANK, R.E. (1995) Maintaining buyer-supplier partnerships, International Journal of Purchasing and Materials Management, 31(3), pp. 311.

LASCELLES, D. \& DALE, B. (1990) Quality management: the Chief Executive's perception and role, European Management Journal, 8(1), pp. 67-75.

LEWIS, D. (1996a) The organizational culture saga - from OD to TQM: a critical review of the literature, Leadership \& Organization Development Journal, 17(1), pp. 12-19.

LEWIS, D. (1996b) Part 2 - applications, Leadership \& Organization Development Journal, 
17(2), pp. 9-16.

LONGNECKER, C.O. \& SCAZZERO, J.A. (1993) Total quality management from theory to practice: a case study, International Journal of Quality \& Reliability Management, 10(5), pp. 24-31.

MANN, R.S. \& KEHOE, D.F. (1994) The quality improvement activities of total quality management (paper 1), Quality World Technical Supplement, March, pp. 43-56.

MAULL, R., BROWN, P. \& CLIFFE, R. (2001) Organisational culture and quality improvement, International Journal of Operations and Production Management, 21(3), pp. 302-326.

MAYO, E. (1960) The Human Problems of an Industrial Civilization (New York, The Viking Press).

MCADAM, R. \& LEONARD, D. (2001), Developing TQM: The knowledge management contribution, Journal of General Management, 26(4), pp. 47-61.

MCDONALD, F. \& DIERKES, M. (1999) The importance of power in partnership relationships, Journal of General Management, 25(10), pp. 43-59.

MCHUGH, M. (2003) Buyer-supplier relationships and organizational health, Journal of Supply Chain Management, 39(2), pp. 15-25.

MCNABB, D.E. \& SEPIC, F.T. (1995) Culture, climate, and total quality management: measuring readiness for change, Public Productivity \& Management Review, 18(4), pp. 369385.

MCSHANE, S.L. (1998) Organizational Behaviour (Toronto, McGraw Hill).

MEHRA, S., HOFFMAN, J.M. \& SIRIAS, D. (2001) TQM as a management strategy for the next millennium, International Journal or Operations and Production Management, 21(5/6), 
pp. 855-876.

MOLLER, M., JOHANSEN, J. \& BOER, H. (2003) Managing buyer-supplier relationships and inter-organisational competence development, Integrated Manufacturing Systems, 14(4), pp. 369-379.

MORROW, P.C. (1997) The measurement of TQM principles and work-related outcomes, Journal of Organizational Behaviour, 18(4), pp. 363-376.

NELSON JOSEPH, I., RAJENDRAN, C., KAMALANABHAN, T.J. \& ANANTHARAMAN, R.N. (1999) Organizational factors and total quality management - an empirical study, International Journal of Production Research, 37(6), pp. 1337-1352.

O’REILLY, C.A. III \& CHATMAN, J.A. (1996) Culture as social control: Corporations, cults, and commitment. In Staw, B.M. \& Cummings, L.L. (Eds.) Research in organizational behaviour, 18, pp. 157-200 (Greenwich, JAI Press).

OLIVER, N. (1990) Employee commitment and total quality control, International Journal of Quality and Reliability Management, 7(1), pp. 21-29.

PALMER, R. \& WILSON, J.P. (1995) Maintaining the energy for commitment to quality, Training for Quality, 3(2), pp. 9-13.

PRAJOGO, D. \& SOHAL, A.S. (2004) The sustainability and evolution of quality improvement programmes - an Australian case study, Total Quality Management \& Business Excellence, 15(2), pp. 205-220.

PORTER, L.J. \& PARKER, A.J. (1993) Total quality management - the critical success factors, Total Quality Management, 4(1), pp. 13-22.

REDMAN, T. \& GRIEVES, J. (1999) Managing strategic change through TQM: Learning from failure, New Technology, Work \& Employment, 14(1), pp. 45-62. 
REES. C. (1999) Teamworking and service quality: the limits of employee involvement, Personnel Review, 28(5/6), pp. 455-473.

REGER, R.K., GUSTAFSON, L.T., DEMARIE, S.M. \& MULLANE, J.V. (1994)

Reframing the organisation: why implementing total quality is easier said than done, Academy of Management Review, 19(3), pp. 565-584.

RODRIGUES, C.A. (1994) Employee participation and empowerment programs, Empowerment in Organizations, 2(2), pp. 29-40.

SARAPH, J.V. \& SEBASTIAN, R.J. (1993) Developing a quality culture, Quality Progress, 26(9), pp. 73-78.

SATHE, V. (1983) Implications of corporate culture: a manger's guide to action, Organizational Dynamics, Autumn, pp. 5-23.

SCHEIN, E.H. (1996) Organizational Culture and Leadership (San Francisco, Jossey-Bass).

SCHONBERGER, R.J. (1992) Is strategy strategic? Impact of total quality management on strategy, Academy of Management Executive, 6(3), pp. 80-87.

SCHONBERGER, R.J. (1994) Total quality: teamsmanship over leadership, Benchmarking for Quality Management \& Technology, 1(1), pp. 38-47.

SCIENCE \& ENGINEERING POLICY STUDIES UNIT. (1994) UK Quality Management Policy Options, SEPSU Policy Study 10 (London, The Royal Society and Royal Academy of Engineering).

SILA, I. \& EBRAHIMPOUR, M. (2003) Examination and comparison of the critical factors of total quality management (TQM) across countries, International Journal of Production Research, 41(2), pp. 235-268.

SILOS, I.M. (1999) Employee involvement - a component of total quality management, 
Production and Inventory Management Journal, 40(1), pp. 56-65.

SINCLAIR, J. \& COLLINS, D. (1994) Towards a quality culture ?, International Journal of Quality \& Reliability Management, 11(5), pp. 19-29.

SIROTA, D., USILANER, B. \& WEBER, M.S. (1994) Breaking through the cultural wall, Journal for Quality and Participation, 17(2), pp. 74-83.

SITKIN, S.B., SUTCLIFFE, K.M. \& SCHROEDER, R.G. (1994) Distinguishing control from learning in total quality management: a contingency perspective, Academy of Management Review, 19(3), pp. 537-564.

SMIRCICH, L. (1983) Concepts of culture and organizational analysis, Administrative Science Quarterly, 28, pp. 339-358.

SNAPE, E., WILKINSON, A., MARCHINGTON, M. \& REDMAN, T. (1995) Managing human resources for TQM: possibilities and pitfalls, Employee Relations, 17(3), pp. 42-51.

STAUSS, B. (1995) Internal services: classification and quality management, International Journal of Service Industry Management, 6(2), pp. 62- 88.

STREBEL, P. (1996) Why do employees resist change?, Harvard Business Review, MayJune, pp. 86-92.

STUART, F.I. (1993) Supplier partnerships: influencing factors and strategic benefits, International Journal of Purchasing and Materials Management, 29(4), pp. 22-28.

TATA, J. \& PRASAD, S. (1998) Cultural and structural constraints on total quality management implementation, Total Quality Management, 9(8), pp. 703-710.

TAYLOR, F.W. (1947) Principles of Scientific Management (New York, Harper \& Row).

TAYLOR, W.A. \& WRIGHT, G.H. (2003) The impact of senior manager's commitment on 
the success of TQM programmes: an empirical study, International Journal of Manpower, 24(5), pp. 535-550.

THOMPSON, K.R. (1998) Confronting the paradoxes in total quality management, Organizational Dynamics, 26(3), pp. 62-74.

TROMPENAARS, F. \& HAMPDEN-TURNER, C. (1998) Riding the Waves of Culture: Understanding Diversity in Global Business (New York, McGraw-Hill).

TUCKMAN, A. (1994) The yellow brick road: total quality management and the restructuring of organizational culture, Organization Studies, 15(5), pp. 727-751.

UGBORO, I.O. \& OBENG, K. (2000) Top management leadership, employee empowerment, job satisfaction, and customer satisfaction in TQM organizations: an empirical study, Journal of Quality Management, 5(2), pp. 247-272.

URWICK, L.F. (1944) The Elements of Administration (London, Pitman \& Sons).

VAN AKEN, E.M., MONETTA, D.J. \& SINK, D.S. (1994) Affinity groups: the missing link in employee involvement, Organizational Dynamics, 22(4), pp. 38-55.

VAN DONK, D.P. \& SANDERS, G. (1993) Organizational culture as a missing link in quality management, International Journal of Quality \& Reliability Management, 10(5), pp. $5-15$.

WALTON, R.E. (1989) Up and Running: Integrating Information Technology and the Organisation (Boston, Harvard Business School Press).

WHITTLE, S., SMITH, S., TRANFIELD, D. \& FOSTER, M. (1992) Implementing total quality", International Journal of Technology Management, 7(4/5) Special Issue, pp. 235243.

WILCOX, M., DALE, B.G., BOADEN , R.J. \& MCQUATER, R.E. (1996) Managing for 
quality: the strategic issues, International Journal of Technology Management, 12(1), pp. 5974.

WILKINSON, A. (1992) The other side of quality: 'soft' issues and the human resource dimension, Total Quality Management, 3(3), pp. 323.

WILKINSON, A., MARCHINGTON, M. \& GOODMAN, J. (1992) Total quality management and employee involvement, Human Resource Management Journal, 2(4), pp. 120.

WILKINSON, A., REDMAN, T. \& SNAPE, E. (1995) New patterns of quality management in the United Kingdom, Quality Management Journal, Winter, pp. 37-51.

WILLIAMS, A.. DOPSON, P. \& WALTERS, M. (1993) Changing culture: New organisational approaches, $2^{\text {nd }}$ Ed. (Wiltshire, Institute of Personnel Management, Cromwell Press).

WILKINSON, A. GODFREY, G. \& MARCHINGTON, M. (1997) Bouquets, brickbats and blinkers: total quality management and employee involvement in practice, Organization Studies, 18(5), pp. 799-819.

WOODWARD, J. (1965) Industrial Organisation: Theory \& Practice (London, Oxford University Press).

YONG, J. \& WILKINSON, A. (1999) The state of total quality management: a review, International Journal of Human Resource Management, 10(1), pp. 137-161.

ZABADA, C., RIVERS, P. \& MUNCHUS, G. (1998) Obstacles to the application of total quality management in health-care organizations, Total Quality Management, 9(1), pp. 57-66.

ZAIRI, M. (1994) Leadership in TQM implementation, The TQM Magazine, 6(6), pp. 9-16. 


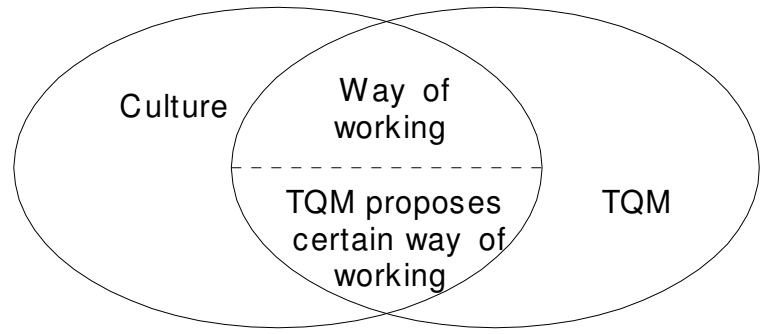

a. Way of working

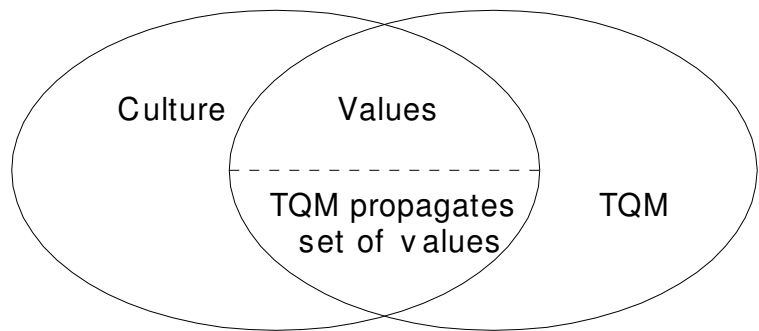

b. System of values

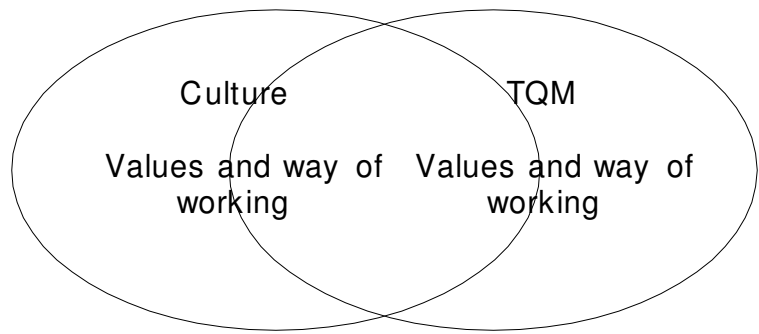

c. System of values and way of working

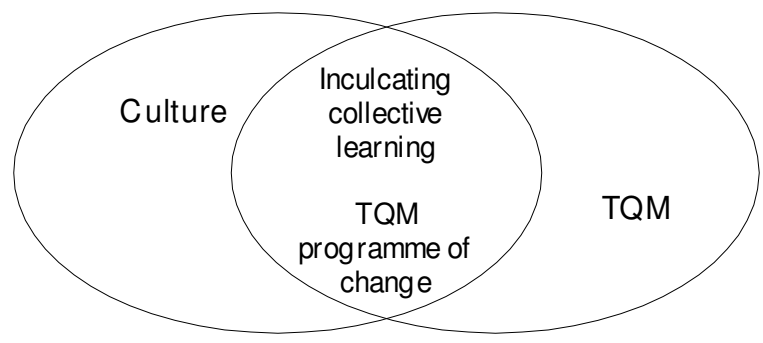

d. Learned entity

Figure 1. Culture and TQM: Areas of overlap 


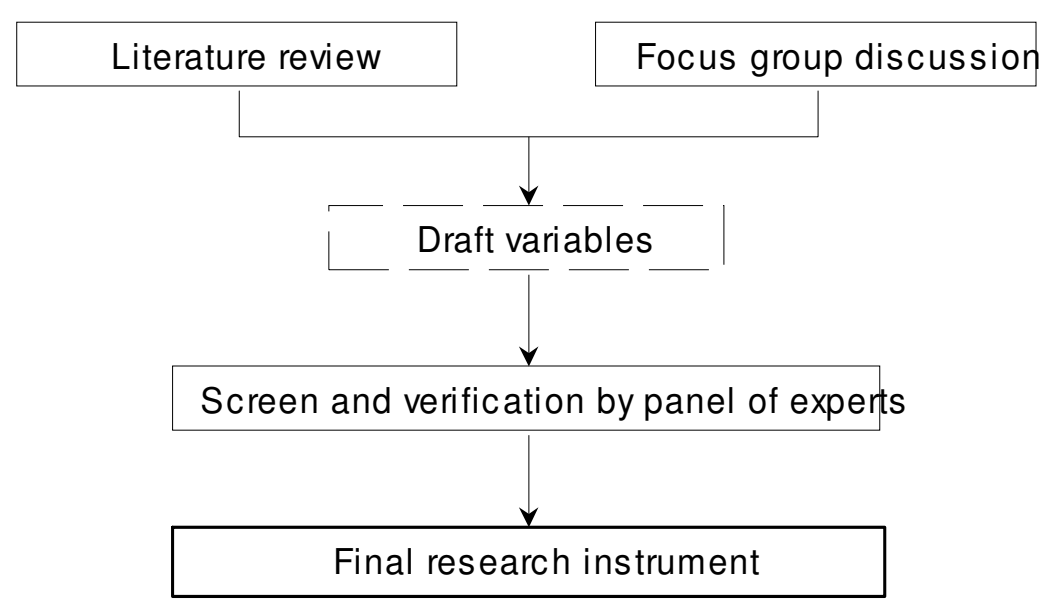

Figure 2. Process used for derivation of the study variables (necessary conditions) 


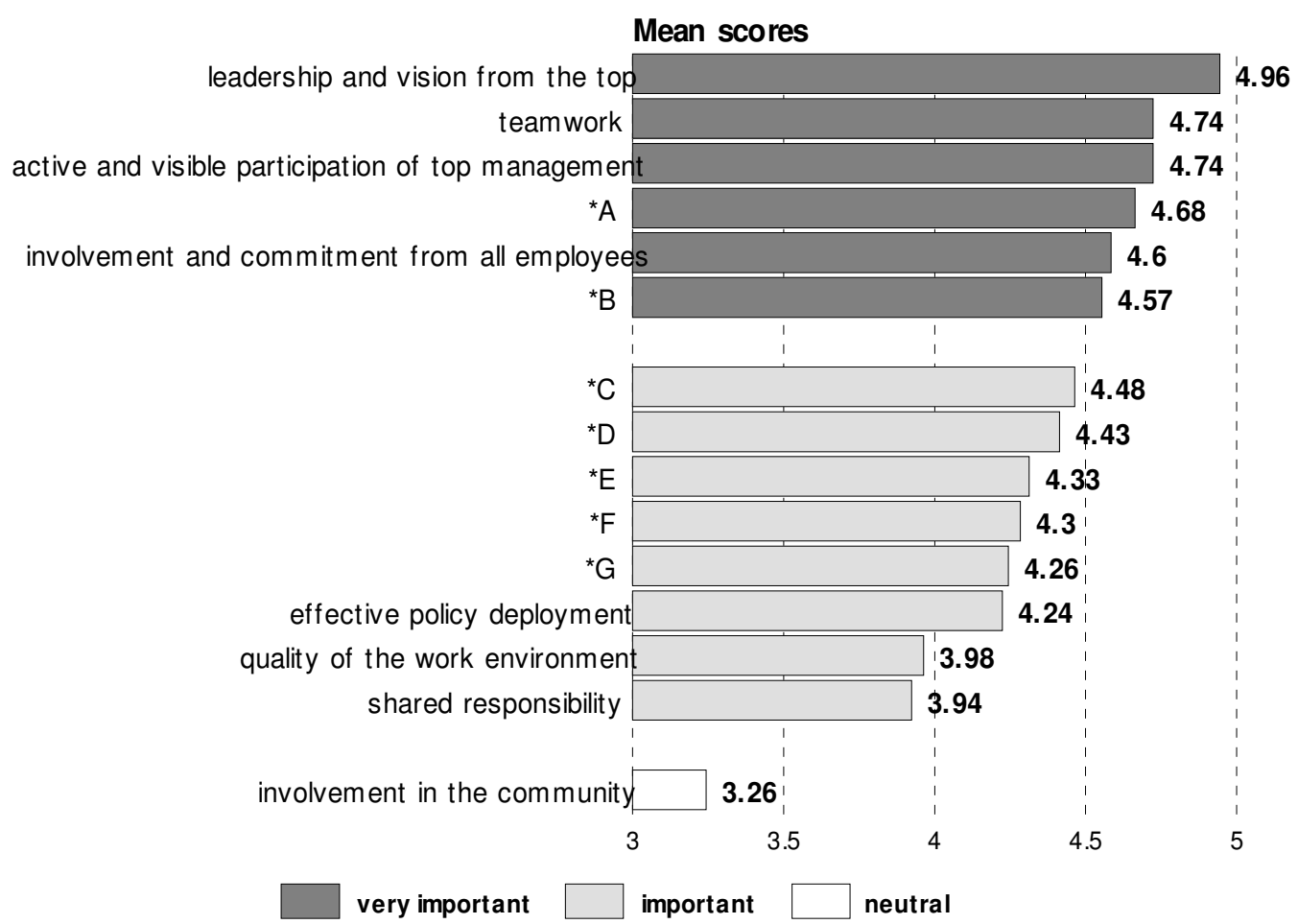

KEY :

A - commitment to and promotion of the TQM concept by the Chief Executive to all levels of the organiz

B - all employees dedicated to continuous (process/working practice) improvement

C - building and maintaining a human environment that allows all members of the organization to improve quality, continually based on mutual trust and collaboration

D - continuous investment in training, and development of all employees skills

E - appropriate partnerships between your organisation and your customers

F - an internal customer/supplier relationship philosophy the objectives of which are understood and committed to by all employees

G - appropriate partnerships between your organization and your suppliers

Figure 3. Mean scores for proposed necessary conditions 
Table 1. Overlap between factors underpinning the successful development of TQM and culture

\begin{tabular}{|c|c|c|c|c|c|}
\hline & Facilitating channel & Learned entity & $\begin{array}{l}\text { Belief/values } \\
\text { system }\end{array}$ & $\begin{array}{c}\text { Mental } \\
\text { programming }\end{array}$ & Way of working \\
\hline \multirow[t]{6}{*}{ Very important } & leadership and vision from the top & & $\checkmark$ & $\checkmark$ & $\checkmark$ \\
\hline & teamwork & & $\checkmark$ & & $\checkmark$ \\
\hline & $\begin{array}{l}\text { active and visible participation of top } \\
\text { management }\end{array}$ & & & & $\checkmark$ \\
\hline & $\begin{array}{l}\text { commitment to and promotion of the TQM } \\
\text { concept by the Chief Executive to all levels of } \\
\text { the organization }\end{array}$ & & & $\checkmark$ & \\
\hline & $\begin{array}{l}\text { involvement and commitment from all } \\
\text { employees }\end{array}$ & & $\checkmark$ & $\checkmark$ & $\checkmark$ \\
\hline & $\begin{array}{l}\text { all employees dedicated to continuous } \\
\text { (process/working practice) improvement }\end{array}$ & $\checkmark$ & $\checkmark$ & & $\checkmark$ \\
\hline \multirow[t]{8}{*}{ Important } & $\begin{array}{l}\text { building and maintaining a human } \\
\text { environment that allows all members of the } \\
\text { organization to improve quality, continually } \\
\text { based on mutual trust and collaboration }\end{array}$ & $\checkmark$ & $\checkmark$ & & \\
\hline & $\begin{array}{l}\text { continuous investment in training, and } \\
\text { development of all employees skills }\end{array}$ & $\checkmark$ & & $\checkmark$ & \\
\hline & $\begin{array}{l}\text { appropriate partnerships between your } \\
\text { organisation and your customers }\end{array}$ & & & & $\checkmark$ \\
\hline & $\begin{array}{l}\text { an internal customer/supplier relationship } \\
\text { philosophy the objectives of which are } \\
\text { understood and committed to by all employees }\end{array}$ & & & $\checkmark$ & $\checkmark$ \\
\hline & $\begin{array}{l}\text { appropriate partnerships between your } \\
\text { organization and your suppliers }\end{array}$ & & & & $\checkmark$ \\
\hline & effective policy deployment & & & & $\checkmark$ \\
\hline & quality of the work environment & & $\checkmark$ & $\checkmark$ & \\
\hline & shared responsibility & & $\checkmark$ & $\checkmark$ & $\checkmark$ \\
\hline
\end{tabular}

